\title{
Regulation of Epidermal Growth Factor and Insulin-like Growth Factor I Receptors by Estradiol and Progesterone in Normal and Neoplastic Endometrial Cell Cultures ${ }^{1}$
}

\author{
R. Kevin Reynolds, ${ }^{2}$ Francisco Talavera, ${ }^{3}$ James A. Roberts, Michael P. Hopkins and K. M. J. Menon \\ Division of Gynecologic Oncology, Department of Obstetrics and Gynecology, University of Michigan Hospitals, \\ Ann Arbor, Michigan 48109-0278
}

Received January 26, 1990

\begin{abstract}
Growth factors are polypeptides which regulate cell proliferation through binding to specific receptor proteins. Normal and neoplastic human endometrium have been shown to express epidermal growth factor (EGF) and insulin-like growth factor I (IGF-1) receptors. Endometrial cell cultures were used to test modulation of EGF and IGF-1 receptors in response to steroid hormones. Endometrial gland and stroma cells were separated by enzymatic dispersion and were incubated in medium containing estradiol $(10,100$, or $1000 \mathrm{pg} / \mathrm{ml})$ or progesterone $(1,10$, or $100 \mathrm{ng} / \mathrm{ml}$ ) followed by radioligand assays. Normal endometrial cultures $(n=6)$ treated with estradiol demonstrated $40 \%$ less EGF binding than control cultures $(P<0.05)$, while IGF-1 binding was unaffected. Stromal cells treated identically decreased in only one treatment group. Progesterone treatment stimulated a significant increase in EGF and IGF-1 receptors in gland cultures. Cultures derived from adenocarcinoma $(n=2)$ demonstrated decreased EGF binding compared with normal endometrium ( $P$ $<0.05$ ). Carcinoma cells treated with progesterone resulted in a dose-dependent increase in EGF binding over control $(P<0.05)$. These data illustrate effects of steroid hormones upon growth factor receptors in human endometrium, and suggest involvement of growth factors in the regulation of normal and neoplastic endometrial growth. (c) 1990 Academic Press, Inc.
\end{abstract}

\section{INTRODUCTION}

The fourth most commonly ocurring cancer of women in the United States arises in the endometrium [1]. A

Presented at the annual meeting of the Society of Gynecologic Uncologists, San Francisco, CA, February 4-7, 1990.

This was supported by the Catherine Brown Fund and the University of Michigan Cancer Research Institute.

${ }^{2}$ Supported by an American Cancer Society Clinical Oncology Fellowship.

${ }^{3}$ Recipient of a National Research Service Award from the National Cancer Institute. causal link between endometrial cancer and estrogen is widely accepted $[2,3]$. Its natural history is thought to include development of atypical hyperplasia, a reversible response of endometrium to aberrant hormonal stimulation, which in a subset of cases progresses to endometrial adenocarcinoma [4]. The cause of this transformation from hyperplasia to malignant neoplasia is not well understood, although growth factor systems and related oncogenes have recently been implicated.

Growth factors are polypeptides which stimulate cell proliferation through binding to specific receptors in target tissues [5]. Two growth factors implicated in reproductive physiology are epidermal growth factor (EGF) and insulin-like growth factor-I (IGF-1). EGF is a wellcharacterized, 53-amino-acid, single-chain peptide with intrachain disulfide bonds that are highly conserved between species [6]. Exposure of target cells to EGF results in activation of a biochemical cascade resulting in DNA synthesis and mitosis [7], although under certain conditions such as low cell density or high ligand concentration, EGF may instead inhibit growth [8]. IGF-1 (somatomedin C) is a 70-amino-acid, single-chain peptide with intrachain disulfide bonds having strongly mitogenic properties [5]. IGF-1 circulates in plasma and is known to bind a specific receptor which resembles the insulin receptor [5]. Receptors for both EGF and IGF-1 have been noted in normal and neoplastic human breast $[9,10]$ and endometrium $[8,11-14]$, in addition to murine and human uterus $[15,16]$.

Growth factors have been implicated in control of both normal and neoplastic growth of many cell types. Growth factor requirements are decreased or nonexistent for transformed cells, whereas normal cells need two or more growth factors to grow [17], suggesting autocrine 
stimulation by growth factors or, alternatively, bypass of the receptor-mediated mitogenic signal pathways. Autocrine stimulation has been demonstrated in several tumors, including, for example, the secretion of an EGF analog by breast carcinoma [18]. In addition, activation of the native EGF receptor can reversibly mimic properties of the transformed phenotype, such as anchorageindependent growth and loss of contact inhibition [19]. Evidence for bypass of receptor-mediated growth control arises from the remarkable similarity of oncogene-coded transforming proteins to growth factor receptors and postreceptor pathways $[19,20]$.

Several studies have shown an interrelationship between hormones and growth factors in the physiology of normal endometrium and related tissues. Uterine EGF receptors in rats increase in response to $17 \beta$-estradiol administered in vivo [21], while rat prostate EGF receptors decrease in response to $5 \alpha$-dihydrotestosterone in vivo [22]. In contrast, progesterone and glucocorticoid effects are variable [21.22]. Human endometrial EGF receptor sites are modulated during the course of the menstrual cycle [11], which may represent the influence of cyclic steroid hormones. In breast, stimulation by the EGF receptor is necessary for expression of the growth stimulatory effects of estrogen [23]. The IGF-1 ligand and associated mRNA increase in the rat uterus in response to $17 \beta$-estradiol [15].

Since unopposed estrogen stimulation is a risk factor for endometrial carcinoma, it is possible that estrogeninduced effects on the EGF and/or IGF-1 receptors may play a role in the development of neoplastic endometrium. The present studies were undertaken to evaluate the presence of EGF and IGF-1 receptors in human endometrial cell cultures of both benign and neoplastic origin, and to test the influence of steroid hormones upon these receptors.

\section{MATERIALS AND METHODS}

\section{Materials}

Mouse EGF (receptor grade) was purchased from Collaborative Research (Bedford, MA). Recombinant IGF1 was a gift from Eli Lilly Research Laboratories (Indianapolis, IN). Nafoxidine hydrochloride was a gift from Upjohn (Kalamazoo, MI). Carrier-free sodium [ $\left.{ }^{125} \mathrm{I}\right]$ iodide was purchased from Amersham (Arlington Heights, IL). All other chemicals and hormones were of highest obtainable grade, and were purchased from Sigma (St. Louis, MO).

Endometrial samples were obtained from either hysterectomy or dilatation and curettage specimens from patients undergoing medically indicated procedures. Six cultures derived from normal endometrium and two cul- tures derived from neoplastic endometrium were utilized for this study. The study was approved by the University of Michigan Institutional Review Board.

\section{Isolation and Culture of Human Endometrial Glands and Stroma}

Endometrium was obtained under sterile conditions and transported to the laboratory. Tissue was processed using the method of Tsang et al. as reported by Randolph et al. [24], and modified using additional refinements [2528]. Briefly, endometrium was minced to $1 \mathrm{~mm}$ cubes in growth medium [McCoy's 5a modified medium without phenol red, $2.2 \mathrm{~g} /$ liter sodium bicarbonate, $0.3 \%$ bovine serum albumin (BSA), $10 \mathrm{~m} M$ Hepes buffer, pH 7.4, 50 $\mu \mathrm{g} / \mathrm{ml}$ gentamicin, $2 \mathrm{U} / \mathrm{ml}$ mycostatin) supplemented with $250 \mathrm{U} / \mathrm{ml}$ collagenase and $1 \mathrm{mg} / \mathrm{ml}$ DNase. Cells were incubated with slow stirring at $37^{\circ} \mathrm{C}$. At $15-\mathrm{min}$ intervals, cell clumps (glands) were allowed to settle. Dispersed cells (stroma) were aspirated, centrifuged at $700 \mathrm{~g}$ for $10 \mathrm{~min}$, and washed three times with growth medium to remove collagenase and DNase. If more than $10 \%$ of the cells were erythrocytes, the cells were separated by centrifugation over a Ficoll gradient. After the 2-hr stromal collection was completed, remaining glands were incubated for an additional $45 \mathrm{~min}$, and were then washed in the same manner described for stromal cells. Gland and stromal cells were then resuspended in growth medium supplemented with $10 \%$ fetal bovine serum (FBS). Viability was assayed using the dye exclusion method [29]. Cells were plated onto 24-well Falcon-Primaria coated dishes (Becton Dickinson Co., Oxnard, CA) at $3 \times 10^{5}$ viable cells per $0.5 \mathrm{ml}$ per well. Cells were incubated at $37^{\circ} \mathrm{C}$ in water-saturated air containing $5 \% \mathrm{CO}_{2}$. Experiments were started after $48-72 \mathrm{hr}$ utilizing FBS which had been charcoal stripped to remove endogenous steroids [30].

\section{Incubation with Steroid Hormones}

Cells were incubated with subphysiologic, physiologic, and pharmacologic concentrations of $17 \beta$-estradiol $(10$, 100 , or $1000 \mathrm{pg} / \mathrm{ml})$ or progesterone $(1,10$, or $100 \mathrm{ng} / \mathrm{ml})$. The competitive estrogen receptor antagonist, nafoxidine hydrochloride, was added to estrogen-treated and control cells at 0.1 and $1 \mu M$ concentrations. Pregnenolone, a steroid without progestogenic activity, was added to untreated cells at the same concentrations as progesterone to serve as a control for the specificity of progesterone effects. Hormones were dissolved in absolute ethanol $(\mathrm{EtOH})$. The final concentration of EtOH was standardized in all cultures at $0.1 \%$. Incubations were performed at intervals ranging from $18 \mathrm{hr}$ to 10 days. Medium was changed every $48 \mathrm{hr}$. Cells were inspected every $48 \mathrm{hr}$ using a phase-contrast microscope with inverted optics. 


\section{Growth Factor Iodination}

lodination of EGF was carried out using the chloramine-T method described by Aharonov et al. [31]. A ratio of $1 \mathrm{mCi}{ }^{125} \mathrm{I}$ for each $5 \mu \mathrm{g}$ of EGF was used. IGF1 was radiolabeled using a modification of the chloramine-T method reported by Chernausek et al. [32]. A ratio of $1 \mathrm{mCi}{ }^{125}$ I for each $1 \mu \mathrm{g}$ IGF-1 was used. Following Sephadex chromatography, the labeled ligand was further purified by the addition of trifluoroacetic acid (TFA, final concentration $0.1 \%$ ) and application to a C18 Sep-Pak cartridge (Waters Milford, MA). The cartridge was washed with $5 \%$ acetonitrile $/ 0.1 \%$ TFA and eluted with $40 \%$ acetonitrile $/ 0.1 \%$ TFA. The eluted fraction was lyophilized and resuspended in phosphate buffer (pH 7.4) with 5\% BSA. Radiolabeled preparations of EGF and IGF-1 were stored at $-20^{\circ} \mathrm{C}$ until use.

\section{Binding Assay}

Cells were washed and then incubated with control medium containing radiolabeled growth factor in the presence or absence of a 200 -fold excess unlabeled ligand. Unless otherwise specified, binding conditions included $0.2 \mathrm{n} M^{125}$ I-EGF or $1.0 \mathrm{n} M^{125}$ I-IGF-1. Incubations for EGF assays were done at $4^{\circ} \mathrm{C}$ for $2 \mathrm{hr}$, and those for IGF-1 assays, at $4^{\circ} \mathrm{C}$ for $16 \mathrm{hr}$. Cells were washed with ice-cold growth medium to remove unbound growth factors, followed by cell lysis with $0.5 \mathrm{~N}$ sodium hydroxide incubated at $37^{\circ} \mathrm{C}$ for $30 \mathrm{~min}$. Bound radioactivity was quantitated in a gamma counter. Specific binding was determined as the difference of nonspecific binding from total binding. Results were standardized by protein content $(100 \mu \mathrm{g}$ per well) as determined by method of the Lowry [33].

\section{RESULTS}

\section{Isolation and Culture of Endometrial Glands and Stroma}

The efficacy of gland and stroma separation was evaluated by microscopic visual inspection and differential counts of the cultures during preparation, and at 48-hr intervals thereafter until each experiment was concluded. Gland cells were large and rounded, and were frequently clumped or in tubular structures, despite enzymatic dispersion. Stroma, in contrast, produced smaller, individual, or fusiform cells. Viability of all cells after enzymatic dispersion was routinely $85-90 \%$. Differential counts routinely revealed $85-90 \%$ initial purity of separation. Erythrocytes, which were the predominant contaminants, were removed on the Ficoll gradient. Figure 1 demonstrates the appearance of gland cells after $48 \mathrm{hr}$ of incubation, while Fig. 2 illustrates stromal cell ap- pearance after $48 \mathrm{hr}$ of incubation. Figures 3 and 4 show the gland and stromal cultures after 8 days of incubation. The predominant cell types remained easily discernable, despite near confluence of each cell type. Cultures demonstrated signs of degeneration including cell detachment and death after 3-4 weeks for gland cells, and after 810 days for stroma. Attempts to maintain long-term cultures of either glands or stroma were unsuccessful.

\section{Characterization of Growth Factor Receptors}

Temperature-dependent binding was tested and was plotted as a function of time. In Fig. 5, time- and temperature-dependent binding data for the EGF receptor in normal endometrial glands are plotted. At room temperature, binding rose to a high, broad peak, and then fell progressively. At $4^{\circ} \mathrm{C}$, binding was decreased, but independent of time following rapid initial saturation. Each point represented the mean of six replicates. Similar data characterizing the IGF receptor demonstrated maximum binding after $16 \mathrm{hr}$ of incubation at $4^{\circ} \mathrm{C}$.

Characterization of EGF receptor affinity was undertaken using Scatchard plot analysis [34]. Normal endometrial glands were incubated with $0.2 \mathrm{n} M{ }^{125} \mathrm{I}$-EGF and increasing concentrations of unlabeled EGF. Figure 6 illustrates binding as a function of the concentration of EGF. The inset Scatchard plot is linear, which is consistent with a single class of receptor binding site. The dissociation constant, $K_{d}$ (slope), was calculated using a computerized linear regression program. The $K_{d}$ was 0.6 $\mathrm{n} M$.

\section{Hormone Treatment}

Normal endometrium. Normal endometrial glands were incubated with $17 \beta$-estradiol or progesterone. Estradiol and progesterone were present in subphysiologic, physiologic, and pharmacologic concentrations. Shortterm incubations of $48 \mathrm{hr}$ demonstrated no changes from control in any group. Incubations of 8 to 10 days demonstrated changes in growth factor binding following treatment with steroids. Binding was performed under optimum conditions for each growth factor, as described under Materials and Methods. In Fig. 7A, treatment with $17 \beta$-estradiol resulted in a decrease of EGF receptors up to $40 \%$ below control. All three estrogen treatment concentrations resulted in statistically significant decreases in EGF receptors versus control $(P<0.05$, ANOVA), but no statistically significant changes were noted between doses. Nafoxidine treatment $(0.1$ and $1 \mu M)$ with and without $17 \beta$-estradiol $(100 \mathrm{pg} / \mathrm{ml})$ resulted in no significant change from control.

In Fig. $7 \mathrm{~B}$, treatment of normal endometrial glands with progesterone resulted in a statistically significant increase in EGF receptors at the two higher doses tested 


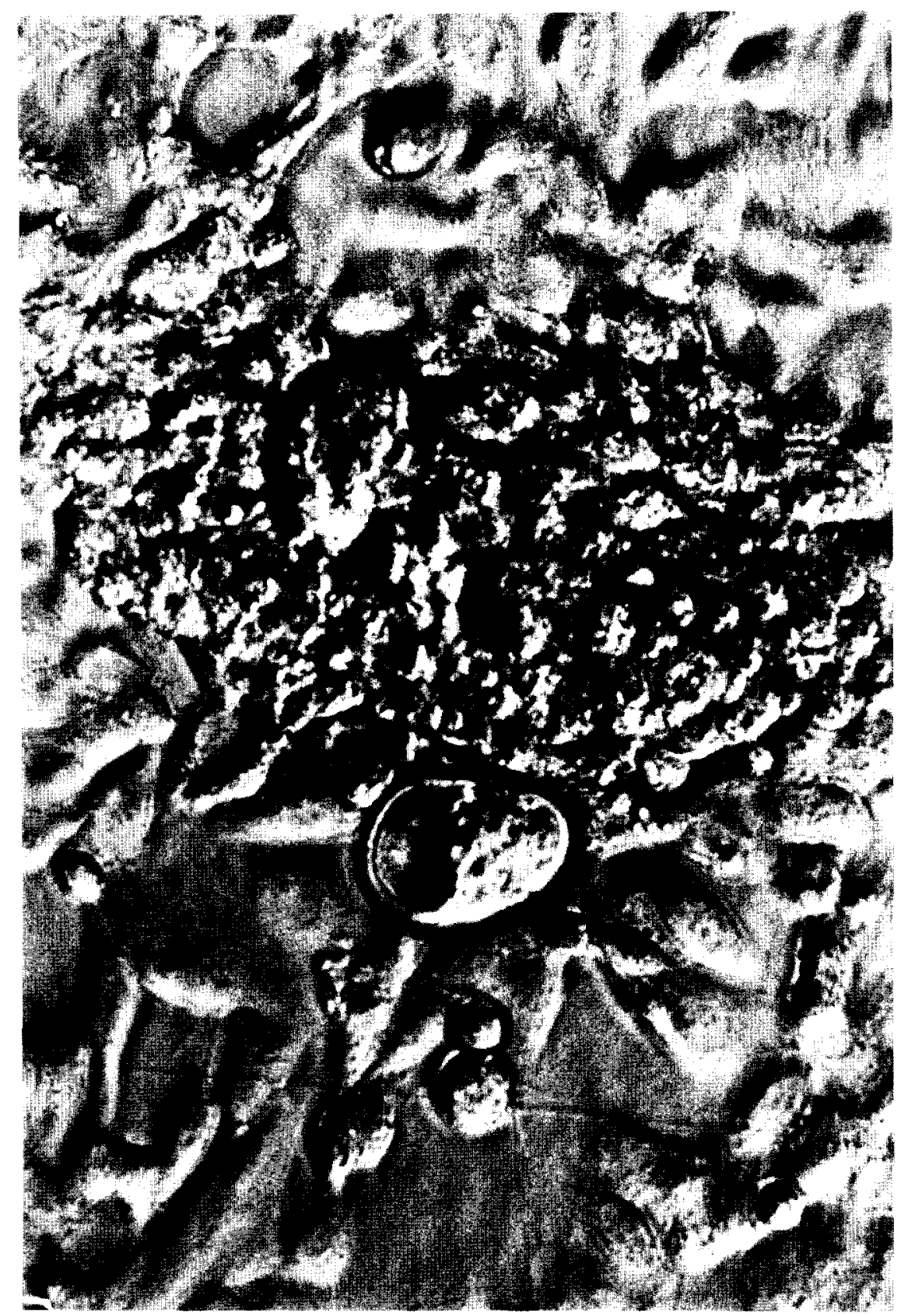

FIG. 1. Endometrial gland culture. This phase-contrast photomicrograph was taken after 48 hr of culture growth. The central clump is a tubular gland which has flattened and spread laterally during culture growth. $\times 400$.

$(P<0.05$, ANOVA). No significant differences were noted between progesterone doses. When physiologic concentrations of progesterone $(10 \mathrm{ng} / \mathrm{ml})$ and $17 \beta$-estradiol $(100 \mathrm{pg} / \mathrm{ml})$ were both present, the resultant EGF binding increased by $35 \%$ over control $(11.9 \mathrm{pg}$ bound versus $8.8 \mathrm{pg}$ bound, $P<0.05$, ANOVA, data not graphed). EGF binding with pregnenolone-treated cells did not differ from control at any concentration tested.

In Figs. 8A and B, normal endometrial stroma was tested using the same conditions described for glands.
The average protein content in each stroma culture dish well was $50 \%$ less than in gland cultures (18.6 $\mu \mathrm{g}$ versus $37.9 \mu \mathrm{g}$, respectively), reflecting fewer cells and early degeneration of stromal cultures. In Fig. 8A, treatment with $17 \beta$-estradiol is depicted, showing a decrease in EGF binding compared with control. Significance $(P<$ 0.05 , ANOVA) was reached only with the lowest incubation dose $(10 \mathrm{pg} / \mathrm{ml})$. Treatment with nafoxidine $-\mathrm{HCl}$ $(0.1$ and $1 \mu M$ ) with and without $17 \beta$-estradiol resulted in no change in EGF binding versus control (data not 


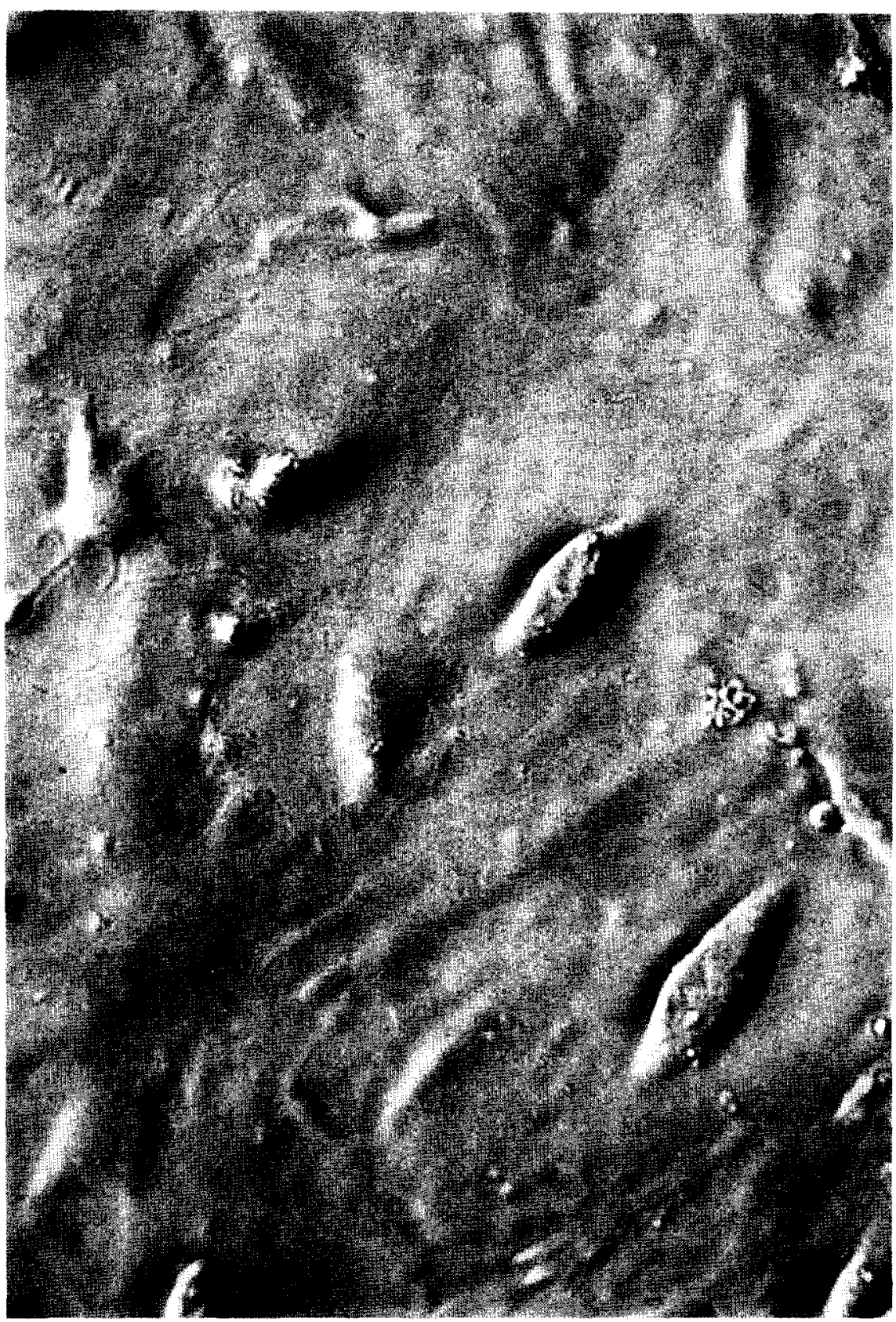

FIG. 2. Endometrial stroma culture. Typical fusiform, nonadherent stromal cells are seen in this phase-contrast photomicrograph taken after $48 \mathrm{hr}$ of culture. $\times 400$.

graphed). In Fig. 8B, treatment of stroma with progesterone is displayed. No significant change in EGF receptor binding was noted in any of the treatment groups.

IGF-1 receptor binding was tested only in normal endometrial gland cultures due to limited availability of cells. Treatment with $17 \beta$-estradiol $(1000 \mathrm{pg} / \mathrm{ml})$ resulted in no significant change from control (Fig. 9), while treatment with progesterone $(100 \mathrm{ng} / \mathrm{ml})$ resulted in a $48 \%$ increase in binding $(P<0.0001$, ANOVA $)$.

Neoplastic endometrium. Cultures derived from two adenocarcinomas of the endometrium (FIGO grades 2 and 3 , respectively) were initiated using the procedures described above. Cells were dispersed enzymatically, but no attempt was made to separate by cell types because of the predominance of a single neoplastic cell type. The cells were incubated with $17 \beta$-estradiol or progesterone. EGF receptor binding did not vary significantly from control for any of the estrogen concentrations (Fig. 10A). Progesterone treatment resulted in a proportional, dosedependent rise in EGF receptor binding $[P<0.5$, AN- 


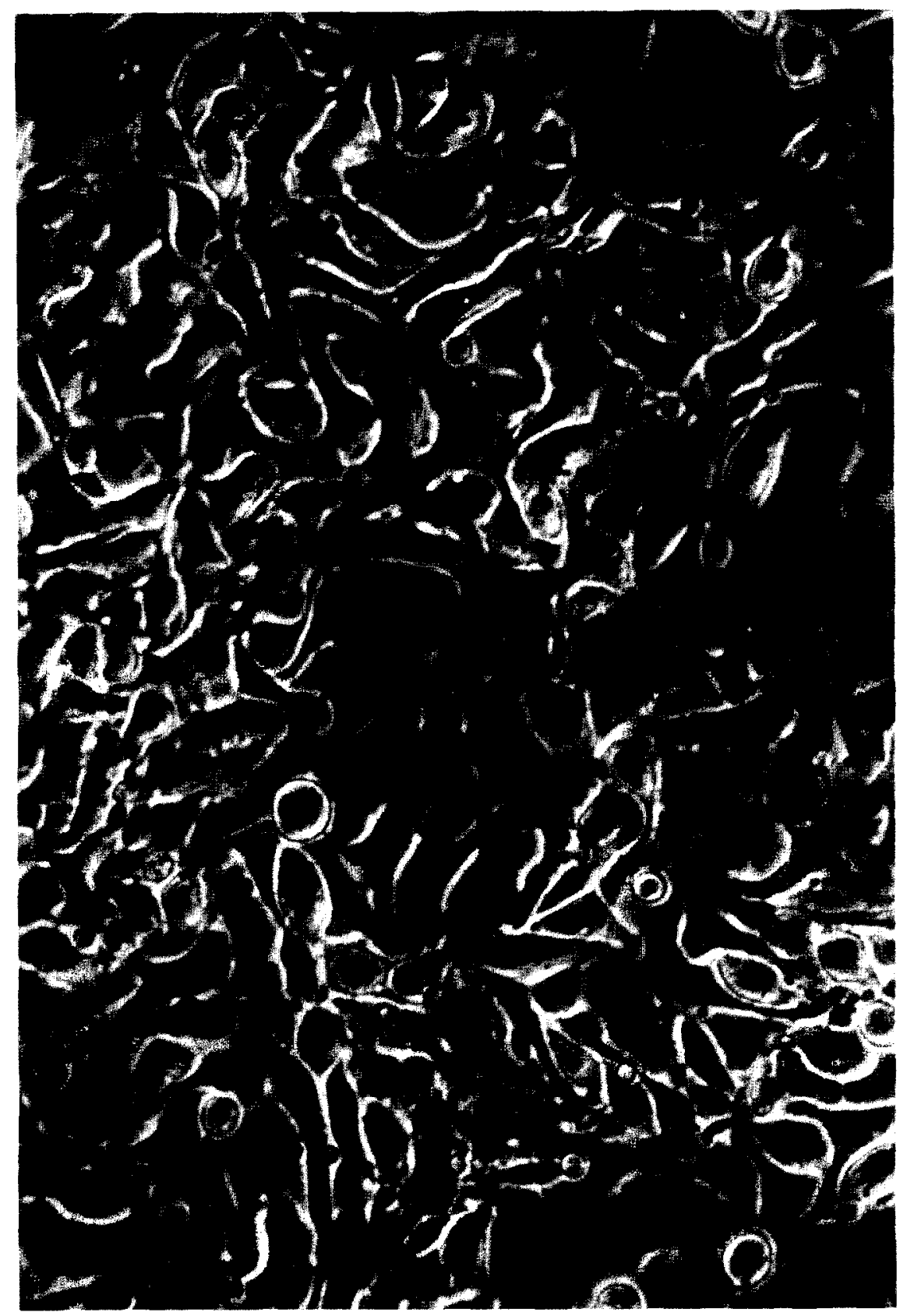

FIC. 3. Fndometrial gland culture (confluent). The tightly packed, swirled arrangement of tadpole-shaped cells represents the appearance of confluent gland cells after 8 days in culture. $\times 400$, phase-contrast micrograph.

OVA, for high dose $(100 \mathrm{ng} / \mathrm{ml})$ versus control and low dose $(1 \mathrm{ng} / \mathrm{ml})]$ (Fig. 10B).

The overall binding noted in the carcinoma control culture was substantially less than the binding noted in normal endometrial glands $(3.4 \mathrm{pg}$ bound $/ 100 \mu \mathrm{g}$ protein versus $22.0 \mathrm{pg}$ bound $/ 100 \mu \mathrm{g}$ protein, $P<0.5$, ANOVA). This relationship was also true when the carcinoma control was compared to the normal stromal control $(3.4 \mathrm{pg}$ bound $/ 100 \mu \mathrm{g}$ protein versus $8.2 \mathrm{pg}$ bound $/ 100 \mu \mathrm{g}$ protein, $P<0.05$, ANOVA).

\section{DISCUSSION}

Techniques for the isolation and culture of endometrial gland and stroma cells have been available for years [2427]. Most techniques are based on enzymatic dispersion and centrifugation, although Satyaswaroop et al. reported a filtration method using stainless-steel sieves to separate tubular glands from individual stromal cells [25]. Morphologic features of glands in culture have been studied by electron microscopy: the presence of cilia, mi- 


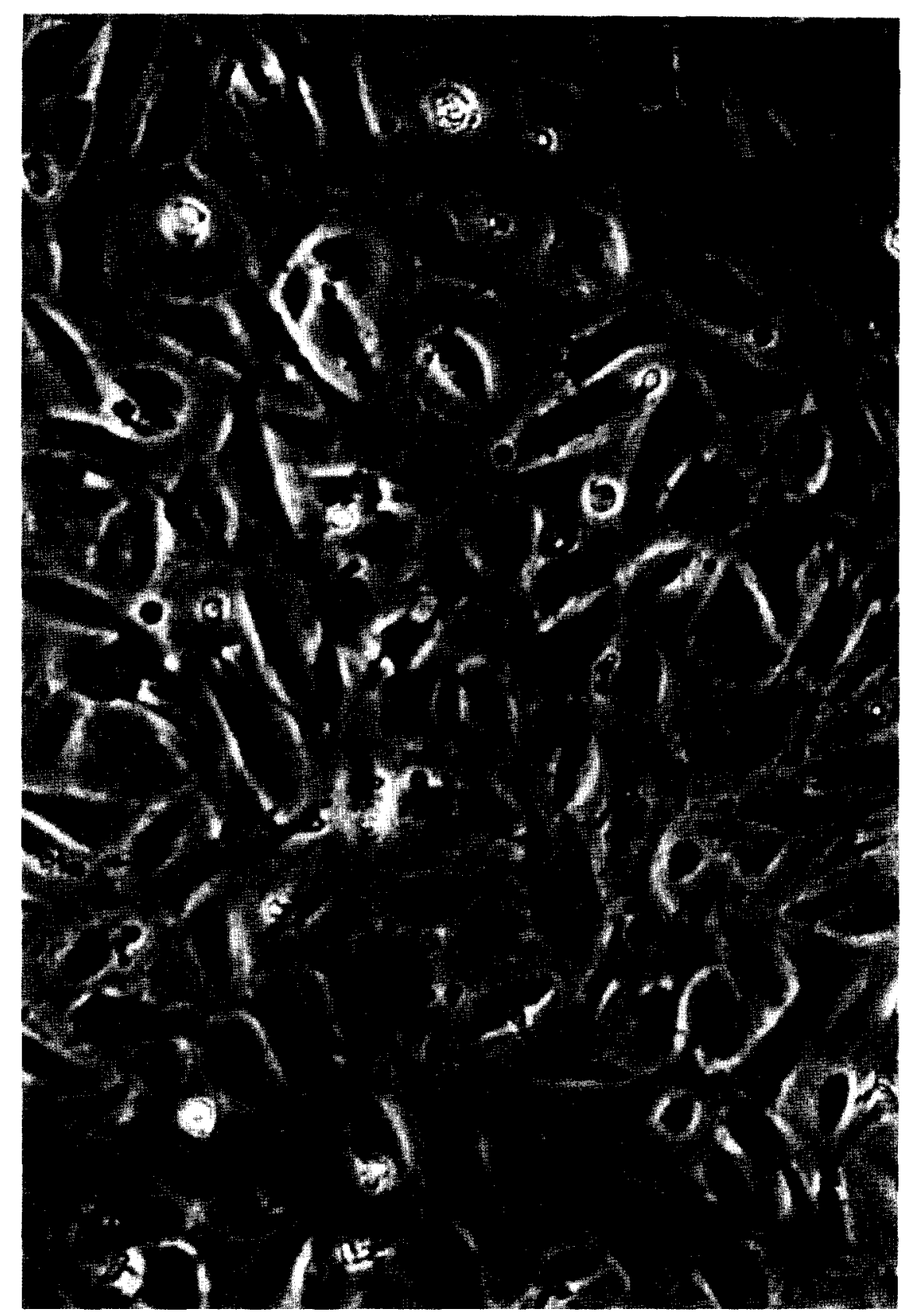

FIG. 4. Endometrial stroma culture (confluent). Confluent stromal cells remain loose and are polyhedral or fusiform in shape. This phasecontrast photomicrograph was taken after 8 days in culture. $\times 400$.

rovilli, desmosomes, and vacuoles is consistent with the epithelial ultrastructure seen in intact endometrium 125 27]. The microscopic appearance of gland cells is that of tightly packed, swirled, tadpole-shaped cells. Our photomicrographs closely resemble the appearance of the gland cultures reported by others [25-27], confirming the purity of our separation. While some authors describe the stroma as a single cell type [24], others acknowledge the presence of several cell types, including fibroblasts and endometrial stroma, among others $[26,27]$. Electron microscopy reveals no cilia, microvilli, or desmosomes [27]. Microscopic examination demonstrates isolated, flat, polygonal (stroma), and elongated (fibroblast) cells. These findings correlate well with the appearance of the stromal cultures reported in this study.

Some authors report success with long-term cultures and endometrium [35-37], although others have been unsuccessful $[24,26,27]$. Varma et al. noted that no ultrastructural documentation of the long-term cultures has been provided to validate the reports [26]. Our own data 


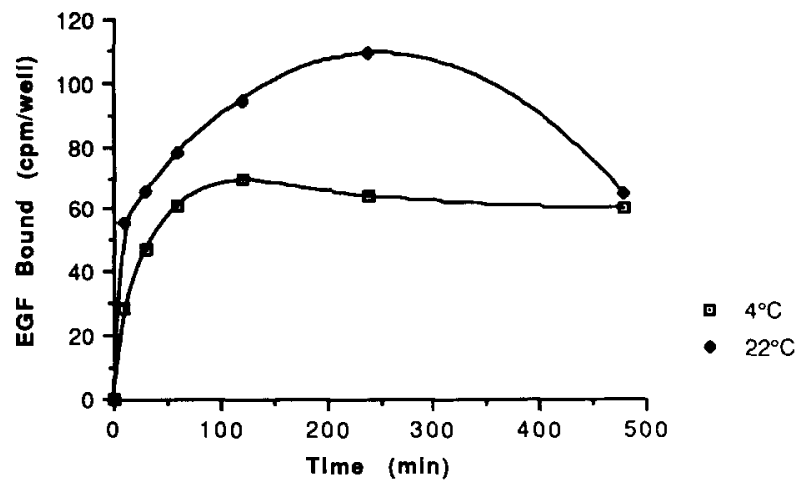

FIG. 5. Time- and temperature-dependent binding characteristics of EGF receptor. Normal endometrial glands were incubated with 0.2 $\mathrm{n} M^{125}$ I-EGF at either 4 or $22^{\circ} \mathrm{C}$ for various time intervals. Nonspecific binding was measured in the presence of 200 -fold excess unlabeled EGF. Each point represents the mean of triplicate measurements. Binding is expressed as counts per minute $(\mathrm{cpm})$ per culture dish well standardized to $100 \mu \mathrm{g}$ protein per well.

confirm the short-term survival of endometrial cultures. Degeneration of some stromal cells during incubation makes interpretation of steroid effects upon these cells difficult.

Properties of the EGF and IGF-1 receptors in normal and neoplastic tissues of many types, have been reported extensively. These data indicate that EGF action in the target cell is mediated by a transmembrane, single-chain glycoprotein receptor with a single ligand binding site [7]. The $K_{d}$ for the EGF receptor has been reported to range between 0.2 and $1.0 \mathrm{n} M[6]$. While the number of receptor sites varies widely between cells of different types, the structure of the receptor itself is a highly conserved $M_{\mathrm{r}} 170,000$ glycoprotein $[1,16,22,38]$. Our Scatchard analysis of the EGF receptor in endometrial cell cultures confirms the saturable nature of the receptor, and the $K_{d}$ of $0.6 \mathrm{n} M$ falls within the established

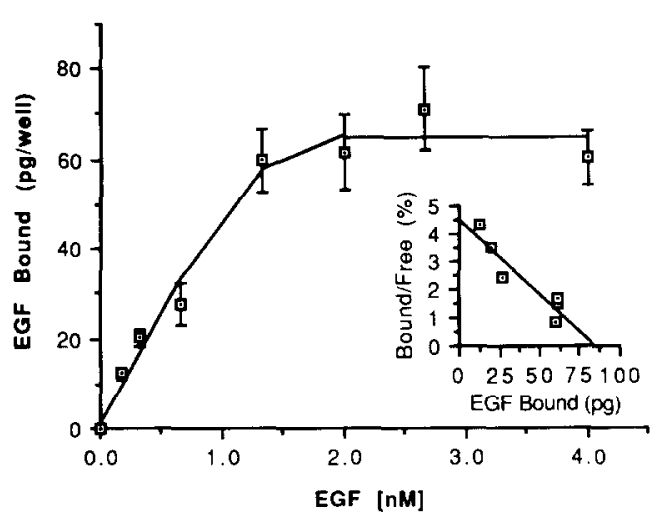

FIG. 6. Saturation characteristics of the EGF receptor. Normal endometrial glands were incubated with $0.2 \mathrm{n} M^{125} \mathrm{I}-\mathrm{EGF}$ and increasing concentrations of unlabeled EGF for $2 \mathrm{hr}$ at $4^{\circ} \mathrm{C}$. Binding is expressed as picograms per culture dish well standardized to $100 \mu \mathrm{g}$ protein, and is plotted against EGF concentration. Each point represents the mean of triplicate measurements. Inset: The Scatchard plot is derived from saturation data. Linear regression using the least-squares method provides the determination of $K_{d}$ (slope). $K_{d}=0.6 \mathrm{n} M$.

range. Earlier work done in our laboratory demonstrated identical receptor characteristics when fresh, uncultured endometrial samples were processed to obtain the membrane fraction [12]. The validity of the culture model for growth factor studies is supported by the fact that $K_{d}$ and saturation properties of the EGF receptor are consistent in cultures and fresh biopsy material.

The IGF-1 receptor is more complex. The receptor is a heterotetrameric glycoprotein consisting of two $M_{\mathrm{r}}$ 135,000 binding domains, and two $M_{\mathrm{r}} 90,000$ signaling domains [39]. A significant homology exists between the IGF-1 receptor and the insulin receptor [39]. Receptors for insulin, IGF-1, and IGF-2 bind each of the three respective ligands with varying affinities [40].

Previously reported data from our laboratory for processed endometrial membranes demonstrated the $K_{d}$ for
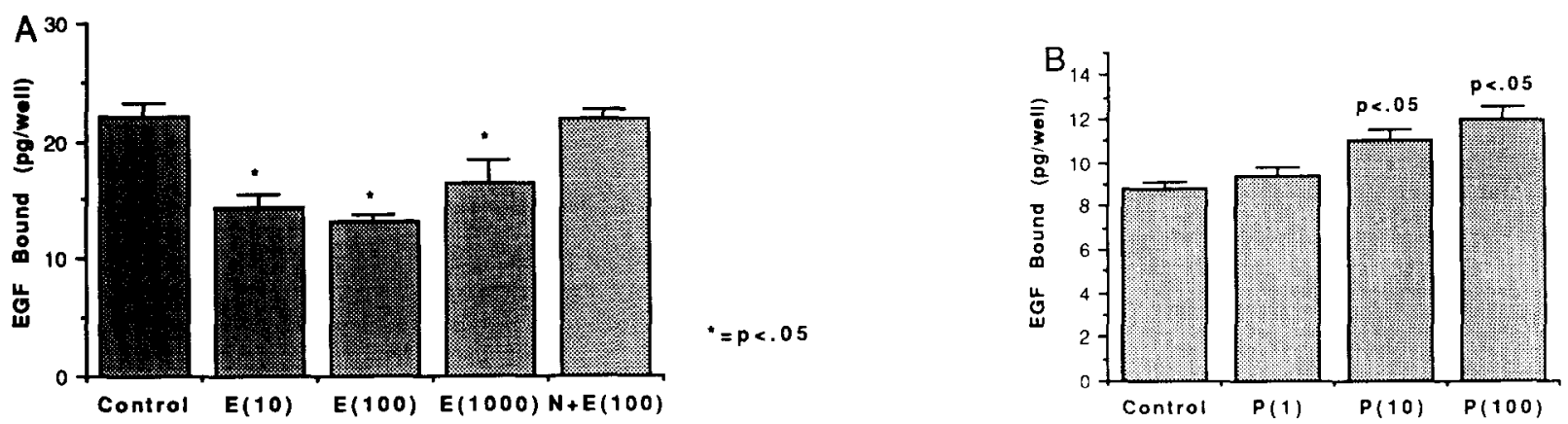

FIG. 7. (A) Incubation of normal endometrial glands for EGF binding assay. Glands were incubated with $17 \beta$-estradiol (10, 100, or 1000 $\mathrm{pg} / \mathrm{ml}) . \mathrm{N}+\mathrm{E}(100)$ represents nafoxidine- $\mathrm{HCl}(1 \mu M)+17 \beta$-estradiol $(100 \mathrm{pg} / \mathrm{ml})$. After 10 days of incubation. EGF binding was assayed. Columns marked by asterisks exhibit statistically significant changes from control $(P<0.05$. ANOVA). (B) Glands were incubated with progesterone $(1,10$, or $100 \mathrm{ng} / \mathrm{ml})$ for 10 days. EGF binding was assayed. Columns on which " $p<.05$ " appears vary significantly from control (ANOVA). Binding is expressed as picograms per culture dish well standardized to $100 \mu \mathrm{g}$ protein. Each column represents the mean of six replicates. 

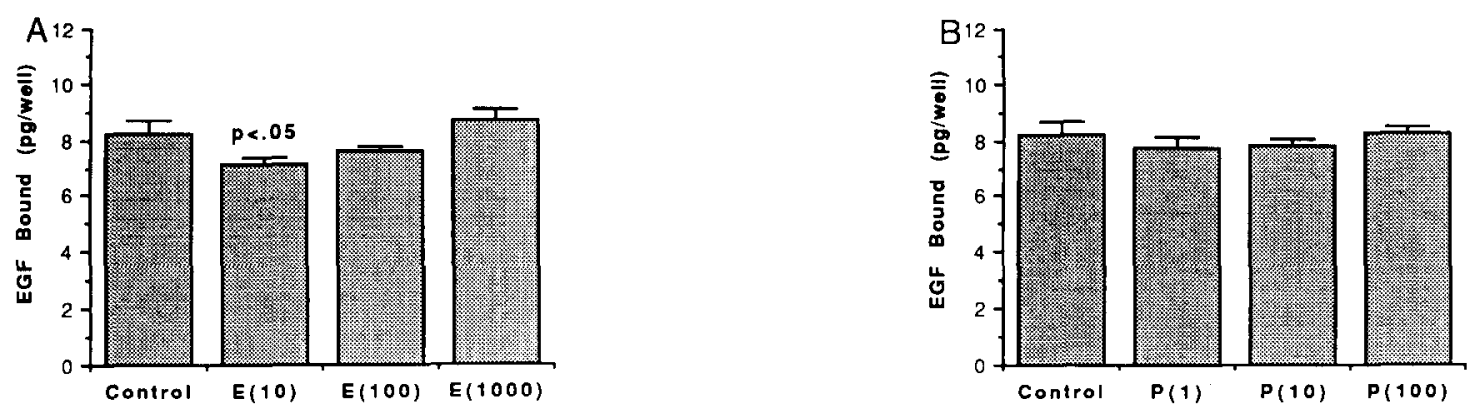

FIG. 8. (A) Incubation of normal endometrial stroma for EGF binding assay. Stromal cells were incubated for 10 days with $17 \beta$-estradiol $(10,100$, or $1000 \mathrm{pg} / \mathrm{ml})$ and EGF binding was assayed. The column on which " $\rho<.05$ " appears varies significantly from control (ANOVA). (B) Stromal cells were incubated for 10 days with progesterone $(1,10$, or $100 \mathrm{ng} / \mathrm{ml})$ and EGF binding was assayed. Binding is expressed as picograms per culture dish well standardized to $100 \mu \mathrm{g}$ protein. Each column represents the mean of five replicates.

IGF-1 receptor to be $4.0 \mathrm{n} M$. Receptor saturability and specificity were also confirmed. Although these observations have not yet been repeated in culture, the validity of comparing EGF receptor data suggests that IGF-1 receptor data derived from cell cultures and processed membranes may also be compared.

Receptor processing by the cell following exposure to growth factors has been best studied for the EGF system. The receptor-ligand complex is rapidly internalized into microvesicular bodies within the cell [41], resulting in downregulation of the receptor. The internalization and downregulation phenomenon explains the decreased binding of EGF observed as a function of time in viable cells (Fig. 5). Incubations at $4^{\circ} \mathrm{C}$ inhibit the metabolic processes necessary for internalization, resulting in stable binding after saturation occurs. IGF-1 binding requires more time to reach binding equilibrium, and is complicated by the short half-life of the ligand at room temperature or above. Nevertheless, the same principles apply to explain binding optimization at $4^{\circ} \mathrm{C}$ for $16 \mathrm{hr}$.

Animal data cited in the Introduction suggest that in hormonally sensitive tissues, estrogen causes EGF re-

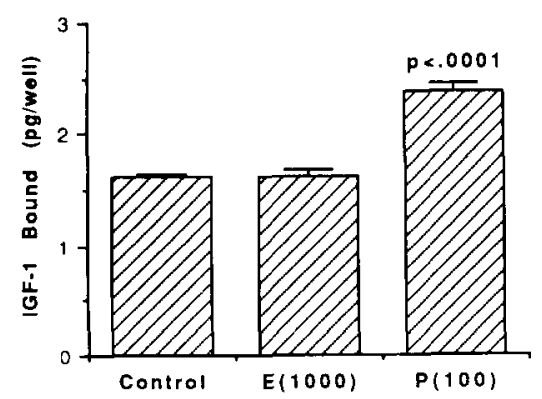

FIG. 9. Incubation of normal endometrial glands for IGF-1 assay. Gland cells were incubated with $17 \beta$-estradiol $(1000 \mathrm{pg} / \mathrm{ml})$ or progesterone $(100 \mathrm{ng} / \mathrm{ml})$ for 10 days. IGF-1 binding was then assayed. Columns represent the means of five replicates. Binding is expressed as picograms per culture dish well. The progesterone sample varies significantly from control $(P<0.0001$, ANOVA). ceptor upregulation, while progesterone has equivocal effects, and testosterone downregulates the receptor $[21,22]$. Uterine tissues exposed to estrogen express increased mRNA for IGF-1, suggesting an autocrine stimulatory mechanism by IGF-1 in response to estrogen [15]. Human endometrial biopsies show an increase in EGF receptors during the proliferative phase. These data indirectly suggest that estrogen upregulates the receptors and that progesterone downregulates the receptors in human endometrium.

The data presented here demonstrate a different time course for response to steroid exposure in vitro compared with in vivo stimulation. Rats responded to exogenous steroids in a number of hours $[21,22]$. Cells in culture demonstrated no effect after 2 days but did show changes after 7 days. These findings are consistent with steroid induction experiments using breast carcinoma cell lines, where responses typically require $2-7$ days to become evident [42].

In normal endometrial cell cultures, estrogen is a downregulator of EGF but not IGF-1 receptors. In carcinoma cells, the downregulatory effect of estrogen is not seen, which may be due to absence of estrogen receptors. In contrast, progesterone acts as an upregulator for both EGF and IGF-1 receptors in normal tissue, and for EGF receptors in neoplastic tissue. These data appear to contradict the expected findings for the EGF receptor based on experiments done in vivo. Differences inherent in the in vitro model include the lack of circulation, functioning organs, and homeostatic regulatory systems which are found in vivo. The response of cells to regulatory events or conditions in vitro and in vivo may not correlate as expected unless the in vitro model is very sophisticated. With these limitations in mind, several possible explanations may account for our observations.

First, estrogen may stimulate autocrine production of EGF, which causes receptor downregulation. EGF has been documented in uterine luminal secretions of the rat 

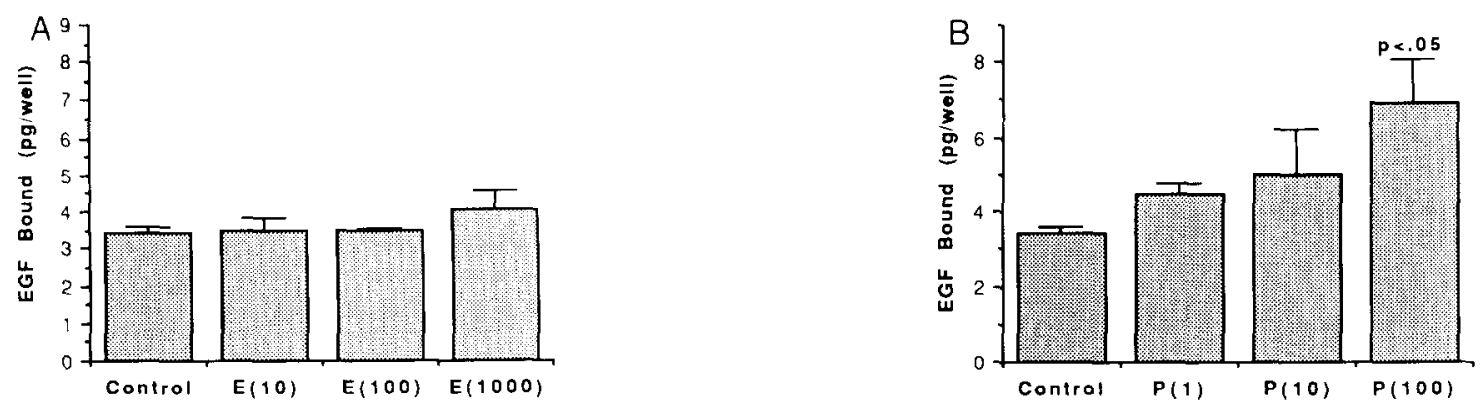

FIG. 10. (A) Incubation of endometrial adenocarcinoma for EGF binding assay. Carcinoma cells were incubated with $17 \beta$-estradiol (10, 100 , or $1000 \mathrm{pg} / \mathrm{ml}$ ) for 10 days and EGF binding was measured. (B) Carcinoma cells were incubated with progesterone (1, 10, or $100 \mathrm{ng} / \mathrm{ml}$ ) for 10 days and EGF binding was measured. The column on which " $p<.05$ " appears varies significantly from both the control group and the $\mathrm{P}(1)$ group. Binding is expressed as picograms per culture dish well standardized to $100 \mu \mathrm{g}$ protein.

[43], which lends support to the existence of an autocrine growth stimulatory mechanism in the uterus. Second, estrogen may stimulate autocrine production of IGF-1 [15]. Although the regulatory influence of IGF-1 upon the EGF receptor has not been conclusively demonstrated, we have previously observed a reciprocal relationship between the receptors for EGF and IGF-1 in human endometrium $[12,13]$. These data are highly suggestive of a regulatory interrelationship. In neoplastic endometrium, we have shown that EGF receptors decrease in proportion to rising tumor grade whereas IGF1 receptors rise in proportion to tumor grade $[12,13]$. This may indicate suppression of the influence of $\mathrm{EGH}$ upon growth regulation of endometrium with increased dependence upon IGF-1 by neoplastic cells. Alternatively, decreased EGF receptors may represent an adaptation by the neoplastic cell which bypasses the growth factor receptor system entirely. Supporting evidence includes the known inhibitory effects of EGF upon the human endometrial carcinoma cell line, RL95-2 [44]. A mechanism explaining bypass of the receptor-mediated pathway may be the ras oncogene product, which is a transforming protein exhibiting properties of the intracellular transduction pathway common to many growth factors. The ras oncogene is known to be expressed in some endometrial carcinomas [45].

Endometrial growth factor receptors are regulated by steroid hormones. The data reported here suggest that EGF and IGF-1 may be important in regulation of endometrial growth in both normal and neoplastic tissue. Ongoing research in our laboratory is directed toward furthering our understanding of the role growth factors play in regulation of endometrial growth.

\section{REFERENCES}

1. Carpenter, G., and Cohen, S. Epidermal growth factor, Annu. Rev. Biochem. 48, 193-216 (1979).

2. Davies, J. L., Rosenshein, N. B., Antunes, C. M. F., and Stolley,
P. D. A review of the risk factors for endometrial carcinoma, Obstet. Gynecol. Surv. 36, 107-116 (1981).

3. Knapp, R. C., and Berkowitz, R. S. Gynecologic oncology, Macmillan. New York (1986).

4. Kurman, R. J., Kaminski, P. F., and Norris, H. J. The behavior of endometrial hyperplasia. A long term study of "untreated" hyperplasia in 170 patients, Cancer 56, 403 (1986).

5. Goustin, A. S., Leof, E. B., Shipley, G. D., and Moses, H. L. Growth factors and cancer, Cancer Res. 46, 1015-1029 (1986).

6. Das, M. Epidermal growth factor: Mechanisms of action, Int. Rev. Cytol. 78, 233-256 (1982).

7. Gill, G. N., Bertics, P. J., Thompson, D. M., Weber, W., and Cochet, C. Structure and regulation of the epidermal growth factor receptor, in Cancer cells. 3. Growth factors and transformation, Cold Spring Harbor Laboratory, Cold Spring Harbor, NY (1985).

8. Korc, M., Haussler, C. A., and Brookman, N. S. Divergent effects of epidermal growth factor and transforming growth factors on a human endometrial carcinoma cell line, Cancer Res. 47, 4909-4914 (1987).

9. Fitzpatrick, S. L., LaChance, M. P., and Schuiz, G. S. Characterization of epidermal growth factor receptor and action on human breast cancer cells in culture, Cancer Res. 44, 3442-3447 (1984).

10. Peyrat, J. F., Bonncterre, J., Beuscart, R., Djianc, J., and Demaille, A. Insulin-like growth factor I receptors in human breast cancer and their relation to estradiol and progesterone receptors. Cancer Res. 48, 6429-6433 (1988).

11. Taketani. Y, and Mizuno, M. Cyclic changes in epidermal growth factor receptor in human endometrium during menstrual cycle, Endocrinol. Japon. 35, 19-25 (1988).

12. Reynolds, R. K., Talavera, F., Roberts, J. A., Hopkins, J. A., and Menon, K. M. J. Characterization of epidermal growth factor receptor in normal and neoplastic human endometrium, presented at Western Society of Gynecologic Oncologists, 19th Annual Meeting (1989).

13. Talavera, F., Reynolds, R. K., Roberts, J. A., and Menon, K. M. J. Insulin-like growth factor I receptors in normal and neoplastic human endometrium, presented at Western Society of Gynecologic Oncologists, 19th Annual Meeting (1989).

14. Batlaglia, F., Scambia, G., Panici, P. B., et al. Epidermal growth factor receptor expression in gynecological malignancies, Gynecol. Obstet. Invest. 27, 42-44 (1989).

15. Murphy, L. J., Murphy, L. C., and Friesen, H. G. Estrogen induces insulin-like growth factor I expression in the rat uterus, $\mathrm{Mol}$. Endocrinol. 1, 445-450 (1987). 
16. Mukku, V. R., and Stancel, G. M. Receptors for epidermal growth factor in the rat uterus, Endocrinology 117, 149-154 (1985).

17. Barnes, D., and Sato, G. Serum-free cell culture: A unifying approach, Cell 22, 649-655 (1980).

18. Dickson, R. B., Huff, K. K., Spencer, E. M., and Lippman, M. E. Induction of epidermal growth factor-related polypeptides by $17 \beta$ estradiol in MCF-7 human breast cancer cells, Endocrinology 118, 138-142 (1986).

19. Stoscheck, C. M., and King, L. E. Role of epidermal growth factor in carcinogenesis, Cancer Res. 46, 1030-1037 (1986).

20. Heidin, C. H., and Westermark, B. Growth factors: Mechanisms of action and relation to oncogenes, Cell 37, 9-20 (1984).

21. Mukku, V. R., and Stancel, G. M. Regulation of epidermal growth factor receptor by estrogen, J. Biol. Chem. 260, 9820-9824 (1985).

22. Traish, A. M., and Wotiz, H. H. Prostatic epidermal growth factor receptors and their regulation by androgens, Endocrinology 121, 1461-1467 (1987).

23. Bates, S. E., Davidson, N. E., Valverius, E. M., et al. Expression of transforming growth factor $\alpha$ and its messenger ribonucleic acid in human breast cancer: Its regulation by estrogen and its possible functional significance, Mol. Endocrinol. 2, 543-555 (1988).

24. Kandolph, J. F., Kipersztok, S., Ayers, J. W. T., Ansbacher, R., Peegel, H., and Menon, K. M. J. The effect of insulin on aromatase activity in isolated human endometrial glands and stroma, Amer. J. Obstet. Gynecol. 157, 1534-1539 (1987).

25. Satyaswaroop, P. G., Bressler, R. S., De la Pena, M. M.. and Gurpide, E. Isolation and culture of human endometrial glands, $J$. Clin. Endocrinol. Metab. 48, 639-641 (1979).

26. Varma, V. A., Melin, S. A., Adamec, T. A., et al. Monolayer culture of human endometrium: Methods of culture and identification of cell types, In Vitro 18, 911-918 (1982).

27. Bongso, A., Gajra, B., Lian, N. P., Wong, P. C., Soon-Chye, N., and Ratnam, S. Establishment of human endometrial cell cultures, Hum. Reprod. 3, 705-713 (1988).

28. Berthios, Y., Katzenellengoben, J. A., and Katzenllenbogen, K. Phenol red in tissue culture media is a weak estrogen: Implications concerning the study of estrogen responsive cells in culture, Proc. Natl. Acad. Sci. USA 83, 2496-2500 (1986).

29. Tenant, J. R. Evaluation of the trypan blue technique for determination of cell viability, Transplantation 2, 685-694 (1988).

30. Sumida, C., Lecerf, F., and Pasqualini, J. R. Control of progesterone receptors in fetal uterine cells in culture: Effects of estradiol, progestins, antiestrogens, and growth factors, Endocrinology 122 , 3-11 (1988)

31. Aharonov, A., Pruss, R. M., and Herschman, H. R. Epidermal growth factor: Relationship between receptor regulation and mitogenesis in 3T3 cells, J. Biol. Chem. 253, 3970-3977 (1978).

32. Chernausek, S. D., Beach, D. C., Banach, W., and Sperling, M. A. Characteristics of hepatic receptors for somatomedin $\mathrm{c} /$ insulin-like growth factor I and insulin in the developing human, J. Clin. Endocrinol. Metab. 64, 737-743 (1987).

33. Lowry, O. H., Rosebrough, N. J., Farr, A. L., and Randall, R. J. Protein measurement with the Folin phenol reagent, J. Biol. Chem. 193, 265-275 (1951).

34. Scatchard, G. The attractions of proteins for small molecules and ions, Ann. NY Acad. Sci. 51, 660 (1949).

35. Trent, J. M., Davis, J. R., and Payne, C. M. The establishment and morphologic characterization of finite cell lines from normal human endometrium, Amer. J. Obstet. Gynecol. 136, 352-362 (1980).

36. Liu, H., and Tseng, L. Estradiol metabolism in isolated human endometrial epithelial glands and stromal cells, Endocrinology 104, 1674-1681 (1979).

37. Chen, L., Linder, H., and Lancet, M. Mitogenic action of oestradiol-17 $\beta$ on human myometrial and endometrial cells in longterm cultures, J. Endocrinol. 59, 87-97 (1973).

38. Buhrow, S. A.. Cohen, S., and Staros, J. V. Affinity labelling of the protein kinase associated with the epidermal growth factor receptor in membrane vesicles from A431 cells, J. Biol. Chem. 257, 4019-4022 (1982).

39. Ullrich, A., Gray, A., Tam, A., et al. IGF-1 receptor primary structure: Comparison with insulin receptor suggests structural determinants that define functional specificity, $E M B O J .5,2503-$ 2512 (1986)

40. Adashi, E., Resnick, C., D'Ercole, J., Svoboda, M., and Van Wyk, $\mathrm{J}$. Insulin-like growth factors as intraovarian regulators of granulosa cell growth and function, Endocr. Rev. 6, 400-420 (1985).

41. Haigler, H., McKanna, J., and Cohen, S. Rapid stimulation of pinocytosis in human carcinoma cells $\mathrm{A} 431$ by epidermal growth factor, J. Cell Biol. 83, 82-90 (1976).

42. Sarup, J., Rao, K., and Fox, F. Decreased progesterone binding and attenuated progesterone action in cultured human breast carcinoma cells treated with EGF, Cancer Res. 48, 5071-5078 (1988).

43. Imai, Y. Epidermal growth factor in rat uterine luminal fluid in 64 th Annual Meeting of the Endocrine Society, Abstract 182 (1982).

44. Korc, M., Padilla, J., and Grosso, D. EGF inhibits the proliferation of a human endometrial carcinoma cell line, J. Clin. Endocrinol. Metab. 62, 874-880 (1986).

45. Long, C. A., O'Brien, T. J., Saunders, M. M., Bard, D. S., and Quirk, J. G. ras oncogene is expressed in adenocarcinoma of the endometrium, Amer. J. Obstet. Gynecol. 159, 1512-1516 (1988). 